This item was submitted to Loughborough's Research Repository by the author.

Items in Figshare are protected by copyright, with all rights reserved, unless otherwise indicated.

\title{
The EU and regional integration in West Africa: what effects on conflict resolution and transformation?
}

PLEASE CITE THE PUBLISHED VERSION

http://www.palgrave.com/in/book/9783319475295

PUBLISHER

(C) Palgrave Macmillan

VERSION

AM (Accepted Manuscript)

LICENCE

CC BY-NC-ND 4.0

\section{REPOSITORY RECORD}

Piccolino, Giulia, and Stephanie Minou. 2019. "The EU and Regional Integration in West Africa: What Effects on Conflict Resolution and Transformation?”. figshare. https://hdl.handle.net/2134/22858. 


\title{
5. The EU and regional integration in West Africa: what effects on conflict transformation?
}

\author{
Giulia Piccolino and Stephanie Minou
}

\section{Introduction: dynamics of conflict in West Africa}

According to most conventional definitions, West Africa includes sixteen geographically proximate and contiguous states, stretching between the border of the Sahara desert and the Gulf of Guinea. ${ }^{14}$ These countries have in common a history marked by European colonialism and are among the poorest countries of the world, albeit they have recently experienced high growth rates. Following the end of the Cold War, West Africa came to be viewed as one of the most unstable regions in the world (Kaplan 1994). While interstate conflicts have been rare (Kacowicz 1997), numerous intrastate conflicts and security crises have plagued the region over the past two decades.

West African conflicts have deep socio-cultural, political and economic roots, including weak governance structures and corruption, economic inequality and poverty, youth

14 These are Benin, Burkina Faso, Cape Verde, Côte d'Ivoire, Gambia, Ghana, Guinea, GuineaBissau, Liberia, Mali, Mauritania, Niger, Nigeria, Senegal, Sierra Leone and Togo. 
unemployment, and religious and ethnic marginalization (Annan 2014; Musah 2009; Olonisakin 2011: 17). Yet the level of violence of West African conflicts has varied widely. Whereas some conflicts, particularly Liberia (1989 and 1999) and Sierra Leone (1991) were particularly violent and resulted in massive casualties and deaths, others, such as the Casamance conflict in Senegal, the Dagbon crisis in Ghana and the Niger Delta conflict in Nigeria, were low-intensity (Olonisakin 2011: 17).

Today, West Africa's security situation is different from what it was in the 1990s, when the country was shaken by full scale insurgencies. Yet the region is not fully pacified either, as the recent escalation of the crisis in Northern Nigeria shows.

Although they are usually regarded as internal wars, West African conflicts in fact often embroil regional actors, they are driven by regional networks and have regional spillover effects (Musah 2009; Pugh et al. 2004). In a number of occasions, insurgencies have been supported by neighbouring countries through arms transfers, rear bases, and occasional direct military support. This was the case in Sierra Leone, where the Revolutionary United Front (RUF) rebels were aided by Liberian president Charles Taylor, or in Senegal's Casamance conflict, in which Guinea-Bissau and Gambia were actively involved.

The proliferation of Small Arms and Light Weapons (SALW) and the cross-border movement of militias and mercenaries, aided by the porosity of West African borders, all contribute towards explaining the regional dimension of West African conflicts (Aning and Pokoo 2013; Pugh et al. 2004). Former RUF fighters, for example, later lent their services to fight in conflicts in Liberia, Guinea and Western Côte d'Ivoire. These fighters 
have often mixed with ordinary refugees, using refugee camps situated close to borders as military sanctuaries.

In addition to the regionalization of conventional military threats, recently there has been a rise in unconventional security challenges in the region, such as terrorism, piracy, the trafficking of arms, drugs and persons, food insecurity and climate change (Aning and Pokoo 2013; Mangala 2010; Security Council Report 2011. Recent terror attacks have targeted not only Mali, where jihadist groups were involved in the Tuareg insurgency, but also Burkina Faso and Côte d'Ivoire, two countries that had no previous history of radical islamist violence. Another non-conventional regional threat is that of transnational organized crime, particularly drug trafficking (Aning and Pokoo 2013). The emergence of this phenomenon in the region can be linked to the mounting surveillance and high rates of interdiction now prevailing on classic routes from South America to Europe (Security Council Report 2011). Piracy has also become a growing concern in West Africa (Security Council Report 2011). In its 2013 Annual Report on Piracy, the International Maritime Bureau (IMB) recorded that 51 piracy incidents had taken place off the West African coast in 2013 (IMB 2013).

Conventional and unconventional security threats interact and reinforce each other. Maritime piracy and illicit trafficking generate benefits which in turn allow non-state armed groups and terrorists to acquire weapons, recruit militants and encourage corruption (Francis 2013; UNODC 2013). While there is little consensus on the precise significance of smuggling in explaining conflicts, there is overall agreement that economic factors influence conflict dynamics and 'conflict goods' have sustained several past and recent West African wars (Ballentine and Nitzschke 2003: 2). 
The importance of the regional dimension of West African conflicts and the interaction between traditional and non-convention threats can be illustrated in the ongoing crisis in Northern Mali and Nigeria. The roots of Mali's current political crisis are internal and stem from "decades of fundamental grievances" of the minority Tuareg group, as well as from its aspirations to self-rule (Francis 2013: 4; Bergamaschi 2013). However, the conflict was triggered by external developments, particularly an influx of Malian Tuaregs who had returned to Mali after having fought along with Ghaddafi's army (Francis 2013). It was in this context that the National Movement for the Liberation of Azawad (MNLA) was founded (Bergamaschi 2013; Francis 2013). In turn, the inability of President Amadou Toumani Touré to address effectively the Tuareg rebellion led discontented Malian soldiers to instigate a military coup against him on 22 March 2012 (Bergamaschi 2013; Francis 2013), deepening the crisis. The crisis in Mali is regional also because Tuareg minorities live also in the Sahel and Saharan areas of Niger, Algeria, Burkina Faso and Libya. Moreover, the situation in northern Mali has contributed to the spread of terrorism, enabling the rise of local Islamist groups and providing an additional base for Al-Qaeda in the Islamist Maghreb (AQIM).

An Islamist radical dimension is present also in the insurgency staged by Boko Haram, which has increasingly launched terrorist attacks predominantly in northern Nigeria. Often interpreted literally as 'Western education/civilization is forbidden', Boko Haram is an Islamist sect that seeks to overthrow the Nigerian state and impose strict Islamist Sharia law (Onuoha 2010; Gow, Olonisakin and Dijxhoorn 2013). Initially the group targeted police and military forces but it has increasingly adopted terrorist tactics, mainly in the form of suicide bombings and kidnappings (ICG 2014). It has established a 
presence in Chad and Cameroon, where it was responsible for the kidnapping and subsequent release of the Vice Prime Minister's wife (McFall 2014). The threat of terrorism is further regionalized as there is already evidence of links between Boko Haram and Mali-based insurgent groups (Onapajoa et al. 2012). While Boko Haram thus constitutes a major threat for West Africa, the Nigerian government has long considered the issue as an internal matter. This has limited the potential role of regional organisations in this conflict (Interview African Union (AU) Commission 2014).

West Africa is confronted by numerous challenges that go beyond state borders and require a concerted response. It is likely that the region will be increasingly faced with unconventional security threats in future. However, compared to other parts of Africa, the region also enjoys relatively well established regional institutions.

\section{Regionalism in West Africa}

West African states are members of the African Union (AU), but they have also launched several sub-regional integration initiatives since independence. Two organisations occupy a central role because of their extended membership, ambitions and mandate. These are the Economic Community of West African States (ECOWAS), which is recognized by the AU as the Regional Economic Community (REC) for West Africa; and the Union Economique et Monétaire Ouest Africaine (UEMOA), also known in English as the West African Economic and Monetary Union. 
Born in 1975 and thoroughly restructured in 1993 with the adoption of a revised treaty (ECOWAS 1993), ECOWAS is the only organisation that includes all West African states, except Mauritania, as its members. Initially, its main goal was the creation of a regional common market, but, while its economic agenda has experienced delays, it has gradually expanded its mandate in the political and conflict management domains.

Regional economic cooperation between the French speaking countries of West Africa is older. Its key pillar is a common currency, the CFA Franc, created in 1945, at the time of colonial rule, which has the particularity of being pegged to the French Franc, and later the Euro (Claeys and Sindzingre 2003). The West African CFA is managed by the French Treasury and by the Banque Centrale des Etats de l'Afrique de l'Ouest (BCEAO). Since 1994, the BCEAO is placed under the authority of UEMOA, an organisation with broader socio-economic goals than purely monetary policy. UEMOA originated from the restructuring of a pre-existing organisation, the Communauté Economique de l'Afrique de l'Ouest (CEAO). It groups together all French-speaking countries of West Africa, with the exception of Mauritania and Guinea Conakry, as well as Guinea Bissau. Thus, regional governance in West Africa is characterized by a dualism between the region as a whole and its French-speaking members (Franke 2007).

\section{Economic and trade integration}

Although ECOWAS plays the primary role in the political and security sphere, the economic agendas of ECOWAS and UEMOA overlap (ECOWAS and UEMOA 2006). Both organisations aim at removing barriers to the free circulation of goods and people in the region. UEMOA has established a Custom Union already in 2000, while the ECOWAS Free 
Trade Area was launched in 2010 and the ECOWAS Common External Tariff has taken effect on 1 February 2016. UEMOA nationals can travel with national ID cards within the UEMOA zone, while ECOWAS has abolished visa obligations for ECOWAS citizens in 2000 (ECOWAS 1979; Adepoju 2002: 14).

The creation of a common market faces substantial obstacles however, as evidenced by the fact that formal trade within the region remains underdeveloped (UNECA 2010). This is due to the economic structure of most countries, which is oriented towards the production of primary goods for export to world markets. It is also due to the diverging economic policies of Francophone and Anglophone states, and the huge gap in size, population and economic importance between West African states, notably between Nigeria and the rest of the region. Paradoxically, the region appears more integrated when one looks at informal trade and migration patterns, which are facilitated by the cultural and ethnic bonds that exist among the peoples of the region. However, the relationship between formal and informal integration is controversial and it is not clear if these two sets of processes reinforce or undermine each other (Bach 2003).

The EU has a long history of support, at least in rhetorical terms, for regional economic integration in Sub-Saharan Africa. The Yaoundé Convention with the former French African colonies (1969), the Lomé I - Lomé IV Conventions (1975-1995) and, currently, the Cotonou convention (2000; Commission of the European Union 2012) were all premised in principle on the desirability of trans-regional cooperation. In practice, however, the implementation of the Lomé 1 - Lomé 4 Conventions (1975-1995) manifested a degree of incoherence with the expressed aim to support regional integration (Coste and Egg 1998). The European Community at the time was 
conditioned by France and, while it actively supported the creation of CEAO, to the point that EC officials were involved in the drafting of the CEAO treaty (Asante 1985: 83), it paid little attention to the newly created ECOWAS. Moreover, for the whole period, about 20 percent of the aid labelled as "regional aid" was neither channelled to ECOWAS nor to CEAO/UEMOA, but to the Comité Inter-Etat de Lutte contre la Sécheresse au Sahel (CILSS) (Coste and Egg 1998), which is a technical organisation dealing with humanitarian and environmental issues. The EU's active involvement in promoting integration between the French speaking countries of West Africa, rather than across the region, continued throughout the 1990s. The Secretary General of the European Commission Émile Noël at the time was known to have inspired the drafting of the UEMOA treaty (Grimm 1999: 1). Thereafter, most EU support for regional integration under the 7th (1990-1995) and 8th (1995-2000) European Development Fund (EDF) was directed towards the establishment of UEMOA and its custom union rather than ECOWAS (Grimm 1999: 16).

Since then the EU has started adapting its approach to West African regional integration. The 9th (2000-2007) and 10th (2007-2013) EDF represented a qualitative and quantitative leap in the EU's ambition to support regional integration in West Africa. The financial allocation for regional cooperation was scaled up, with EUR 235 million for the 2002-2007 Regional Indicative Programme (Commission of the European Union 2002a) and EUR 597 million for the 2008-2013 Regional Indicative Programme (Commission of the European Union 2008). The current 2014 - 2020 Regional Indicative Programme further increases the financial envelope to EUR 1150 (Commission of the European Union 2015). 
Since the 9th EDF, the EU's regional partner of choice has been no longer UEMOA, but West Africa as a whole, including all ECOWAS countries and Mauritania. Significantly, there has been no distinct financial allocation for ECOWAS and UEMOA for the 10th and 11th EDF. Furthermore, in line with the new trend of encouraging greater ownership by the beneficiaries of development aid, the EU has started supporting the region's integration agenda - in particular the creation of the ECOWAS custom union - rather than any specific EU-inspired project or programme (ECOWAS 2006: 49).

The reform of the EU-Africa trade regime, foreseen by the Cotonou Agreement, has eventually been accomplished after a period of difficulties between the EU and West African organisations. An Economic Partnership Agreement (EPA) was supposed to be negotiated between the EU and ECOWAS, with UEMOA participating as an observer. Although the EPA was expected to reinforce regionalism, the negotiations dragged on for a decade, and from 2007 to 2014 West African countries fell under three different trade regimes. The EPA negotiations created much tension, with some African countries arguing that they were premised on a misguided neo-liberal ideology and imposed an excessive burden on poor economies. However, a mutually satisfactory outcome seems to have been reached eventually with the signing of the EPA in 2014. The process of implementation is ongoing. The EPA will result in the establishment of a single trade regime between the West African region and the EU and will be is accompanied by an EPA Development Programme (EPADP), whose financial envelope is currently fixed at EUR 6.5 billion.

The role of regional organisations in addressing conflicts 
The link between the creation of a common market and conflict transformation in West Africa is considerably more tenuous than in Europe. The slow progress of ECOWAS's integration agenda, and the fact that both ECOWAS and UEMOA have achieved modest results in increasing intra-regional trade point to a limited effect of economic integration on conflict transformation. West African organisations tend to have an opposite view of the relationship between peace and economic integration, with peace and stability being seen as a necessary precondition for economic integration (Clapham 2001: 60).

Moreover, free circulation of people is often seen in West Africa as a source of security problems, rather than as a means to transform conflicts. This view has likely been reinforced by the recent escalation $\mathrm{f}$ non conventional security threats.

Regional conflict management in West Africa is very much a domain of intervention of ECOWAS, even if UEMOA has showed some interest in the peace and security domain in the last few years and has recently adopted a peace and security strategic programme (UEMOA 2015). Since the 1990s, ECOWAS has developed a specific peace and security agenda and has established dedicated institutions to address regional conflicts. ECOWAS launched its first peace support operation, the ECOWAS Monitoring Group (ECOMOG), with the aim of stopping the Liberian civil war in 1989 (Adebajo 2002). The Liberian operation was highly controversial and achieved mixed results. However, it represented the beginning of a process of rethinking of regional security. ECOWAS today is routinely engaged in preventive diplomacy, and has been involved in many attempts at mediating violent conflicts. Over the last two decades, ECOWAS's peace operations have been undertaken in Sierra Leone (1997), Guinea Bissau (1998), Côte d'Ivoire (2002), Liberia (2003) and ECOWAS has been involved in the 2013 AFISMA mission in Mali. The general 
framework for ECOWAS's peace and conflict-related activities is laid down in the 1999 Protocol Relating to the Mechanism for Conflict Prevention, Management, Resolution, Peacekeeping and Security (Aning, Birikorang and Jaye 2010). ECOWAS's overall approach to peace and security is also shaped by the 2001 Protocol on Democracy and Good Governance (PDGG) and the 2008 ECOWAS Conflict Prevention Framework (ECPF) (Aning, Birikorang and Jaye 2010). These documents establish a link between peace and democracy and espouse a vision of security inspired by the concept of human security, although the term is explicitly used only in the ECPF. At least in principle, the Mechanism for Conflict Prevention, Management, Resolution, Peacekeeping and Security and the PDGG represent also a drift towards supra-nationality. They confer to the Mediation and Security Council broad powers (Aning, Birikorang and Jaye 2010: 76-77, art. 8-14), which provide for the creation of a multidimensional stand-by force that can intervene in a broad range of international and internal conflicts and enable ECOWAS to sanction its members in case of violations of rights and democratic principles (Aning, Birikorang and Jaye 2010: 98-99, art. 1). ECOWAS's recent pro-democracy stance has shaped the way the organisation has reacted strongly in the event of political crises across the region, especially military coups in the region. The organisation has also developed an increasingly sophisticated conflict prevention agenda, whose key component is its Early Warning System (Aning, Birikorang and Jaye 2010: 81-83, art. 2324). The ECPF advocates both operational and structural actions to prevent conflicts, through cooperation both between ECOWAS's different departments and between ECOWAS and its member states, civil society organisations and the private sector. 
The EU has acknowledged belatedly the importance of West Africa's security-driven regionalism (Commission of the European Union 1996), but its role in supporting ECOWAS's conflict-related activities has become increasingly important in recent years. Dialogue between the EU and ECOWAS was established in 1998 as a consequence of the EU's acknowledgement of ECOWAS's role in managing the conflict in Sierra Leone (Nivet 2006). Since 2000, the EU and ECOWAS have held ministerial meetings once or twice a year. These meetings are complemented by meetings between ECOWAS officials and the EU delegations in the region and by a trialogue involving also the UN Office for West Africa (UNOWA) (Nivet 2006: 20). The EU's financial support for ECOWAS's peace and security activities began later, with the 2002-2007 Regional Indicative Programme. It was increased under the $10^{\text {th }}$ EDF, with the "Consolidation of good governance and regional stability" becoming one of the focal sectors of EU-West Africa cooperation. The 11th EDF has seen the trend continuing, with EUR 250 are specifically earmarked to support regional mechanisms and initiatives to promote peace and security (Commission of the European Union 2015). Further EU support for conflict prevention, management and resolution activities undertaken at the regional level has come from aid disbursed beyond the Regional Indicative Programme. The ECOWAS Mission in Côte d'Ivoire (ECOMICI) and the ECOWAS mission in Liberia (ECOMIL), the second operation undertaken in the country after ECOMOG, received special ad hoc contributions (UK 2005). Likewise, the Rapid Reaction Mechanism supported ECOWAS's mediation efforts in Côte d'Ivoire (Lopez Lucia 2012: 19). Since 2004, EU support for the African Peace and Security Architecture has been channelled through the African Peace Facility (APF). This is a special financial instrument managed by the $\mathrm{AU}$, whose main vocation is 
supporting African-led peace operations, but which also supports institutional capacitybuilding and other conflict management activities. To date, the only West African operation that has substantially benefited from APF funding is the AFISMA mission in Mali (Commission of the European Union 2013c), but the APF has also financed ECOWAS's mediation efforts in a number of other countries (Lopez Lucia 2012: 18). The EU's own direct engagement with regional conflicts in West Africa has not been on the same scale as its engagement in other African regions, particularly the Great Lakes (Youngs 2006). Recently, however, the EU has showed an interest in the Sahel crisis, launching Common Security and Defence Policy (CSDP) capacity building missions in Mali and Niger and appointing a regional special representative (Council of the European Union 2013b). The EU also developed a strategy for the Sahel, the first EU regional strategy in Africa (EEAS 2011a).

In conclusion, West African regionalism has increasingly tackled peace and security questions in the area. Notwithstanding its belated response, the EU has developed a broad range of instruments for supporting both regional integration and regional conflict prevention and management in West Africa. The next section discusses the impact of regional integration on conflict transformation and the extent to which success can be attributed to the EU's engagement.

\section{Conflict transformation: Assessing the pathways of influence}


Fully appreciating ECOWAS and UEMOA's impact on peace and security is difficult, as formal regionalism has been only one of the multiple factors determining the stability of the sub-region, together with trends at the global and national level. The evidence suggests that West Africa has not been very successful in tackling the root causes of conflict through regional economic integration following the EU path, both because of the difference in the nature of conflicts and in the economic structures of the two regions. A possible exception is constituted by UEMOA countries, which are both more integrated than the rest of the region and, until the turn of the millennium, looked remarkably stable (Fearon and Laitin 2003: 86). In the last few years, however, this trend has reversed and several major crises - the Ivorian civil war and the Mali crisis have affected UEMOA countries as well. This suggests that the lower incidence of civil wars in former French colonies was to a large extent due to the military arrangements between France and its former colonies, particularly during the Cold War, rather than to the higher level of regional integration (Fearon and Laitin 2003).

Rather than indirectly through economic integration, ECOWAS has attempted to directly prevent, manage and resolve violent conflicts. The organisation has made substantial progress since the $1990 \mathrm{~s}$, but there is still a gap between its political and institutional framework and its actual work on the ground. Most of ECOWAS's peace support operations have been under-resourced and the creation of a regional stand-by force remains fraught with difficulties (Interview ECOWAS Commission 2013a; Interview ECOWAS Commission 2013b).

The recent crisis in Mali and Northern Nigeria, moreover, have highlighted the limits of ECOWAS's conflict prevention and management capabilities. In both cases, two factors 
have hampered ECOWAS's ability to intervene effectively, in spite of the capacity of the Early Warning System to detect the risk of civil war in a timely fashion. First, is the insistence by national authorities to treat conflicts as internal matters, as in the case of Nigeria. Second, is the uneven overlap between the regional conflict complex and the institutional-political region. The Malian conflict, for instance, has involved Algeria, which is not a West African country, while Boko Haram's cross border attacks have affected Cameroon. The case of Mali is particularly meaningful for understanding the challenges that ECOWAS faces, as the organisation initially played a major role, taking the lead in negotiations that eventually resulted into the return to civilian rule after the March 2012 coup (Haysom 2014). However, in organizing the following military response, ECOWAS, whose predominantly coastal countries do not have sufficient troops fit to fight in the desert, was side-lined by the AU and later by the French Operation Serval. A planned ECOWAS mission was transformed in June 2012 into the AU-led International Support Mission in Mali (AFISMA), which was set up with the involvement of non-ECOWAS countries, such as Chad, and was then absorbed into the Multidimensional Integrated Stabilization Mission in Mali (MINUSMA) (Haysom 2014). In spite of these ongoing difficulties, the reduction in the level of West African violence in the last two decades has taken place alongside the re-launch of institutionalized regionalism (Franke 2007). As such, it is reasonable to conclude that regional organisations in West Africa have been relatively successful in containing (although not eliminating) violent conflicts. Are ECOWAS and UEMOA's successes and failures in transforming regional conflicts attributable to the EU's role in the region? And, if so, to 
what extent? The following section maps the way the EU has influenced regional integration and conflict transformation in West Africa.

\section{Compulsion}

The power asymmetries between the EU and West African states and the EU's key role as a development and trade partner facilitate the EU's effort to influence the region through compulsion. In the domain of economic integration, this approach has been evident. Recently, through the Economic Partnership Agreement negotiations, the EU has taken an active role in pressuring ECOWAS into implementing its planned custom union (Interview ECOWAS Commission 2013c), threatening to withdraw market access to West African products otherwise. In the case of UEMOA, the EU's influence has gone further, as the organisation has been established with massive EU technical and financial assistance and the direct involvement of EU officials (Asante 1985; Grimm 1999: 1). On a political level, the EU has introduced democratic conditionality in its aid relations with ACP states in 1995. Although aid conditionality regards bilateral relations with ECOWAS and UEMOA member states, indirectly it has influenced the normative underpinning of ECOWAS's forthcoming approach to peace, security and governance (Lopez Lucia 2012).

The EU's ability to influence ECOWAS and UEMOA through compulsion has also revealed its limits. These stem in part from the EU itself and its difficulty in achieving vertical and horizontal coherence. The post-colonial politics of EU member states has deeply influenced the EU's attitude towards the region. In a long term perspective, the importance of France's post-colonial politics is evident, as exemplified by the EU's long 
history of support for UEMOA and relative neglect of ECOWAS (Asante 1985; Coste and Egg 1998). More recently, the post-colonial connection has led to a preference for bilateral responses with respect to the conflicts in Sierra Leone and Côte d'Ivoire (Youngs 2006). At the same time, inconsistency among different policies has been evident in the negotiation of the EPA. The operationalization of the new trade regime has been a difficult process because, in designing it, the EU initially prioritized its WTO commitments and the promotion of free trade over regional integration and conflict transformation (Stevens 2008).

Another problem concerns the recipients' capacity to absorb aid and translate positive incentives into policy outcomes. Since the EU has stepped up its support for West African regional institutions, ECOWAS and UEMOA's difficulties in absorbing and managing EU aid has been a major issue (EU 2009). In January 2009, the deadline by which all contracts under the 9th EDF had to be signed, more than EUR 5 million had not been committed. The doubling of funds allocated to regional cooperation under the 10th EDF further aggravated the problem (Commission of the European Union 2009a: 28). In November 2013, one month before the expiration of the 10th EDF commitment deadline, the ECOWAS and UEMOA Commissions were still to receive 10th EDF aid, due to their inability to sign a contribution agreement with the EU. EU support for ECOWAS's Regional Peace, Security and Stability Mandate was eventually approved, but it is expected to be financed with EUR 27 million, out of EUR 119 million initially allocated for 2008-2013 to the peace and security envelope.

EU delegations and West African officers have contrasting opinions about the causes of insufficient absorption capacity. EU officers emphasize ECOWAS and UEMOA's lack of 
capacity and organisational skills, while ECOWAS and UEMOA officials complain about the complexity and inadequacy of EU procedures. Moreover, most of ECOWAS and UEMOA's activities fall into the domain of policy formulation and harmonization. They require intensive engagement by ECOWAS and UEMOA staff, but they do not consume a huge amount of funding.

The EU has reacted to ECOWAS and UEMOA's difficulties by supporting the capacities of the two organisations, through activities such as trainings and seminars (Interview EU Delegation to Nigeria and ECOWAS 2013), whose potential impact is, for time being, limited.

\section{Social learning}

Compulsion alone is unlikely to ensure that new norms are adopted and internalized by regional actors. EU incentives and disincentives have indeed been accompanied by efforts to stimulate a process of social learning. One can see this logic at play behind the institutionalization of political dialogue and in the EU's funding of training programmes in West Africa (Interview EU delegation to Nigeria and ECOWAS 2013; Comission of the European Union 2013d). However, the existence and development of a shared normative and epistemic culture among local, regional and international peacebuilding practitioners (Interview KAIPTC 2013) has been at times more important than the direct social learning influence of the EU itself. 
Model setting

When it comes to EU model setting in West Africa, results are somewhat paradoxical. West African organisations have emulated the EU's institutional set-up, and have adopted the EU vision of functional step-by-step integration. More recent developments, such as the transformation of the ECOWAS Secretariat into a Commission in 2008, suggest that the EU model still enjoys wide currency. However, in West Africa there has been a substantial decoupling (Lenz 2013) between the nominal adoption of institutions and norms inspired by the EU-model and the effective functioning of West African regionalism. ECOWAS and UEMOA's EU-inspired institutions lack the human and financial capabilities, or the competences enjoyed by their EU equivalents. Similarly, key principles underpinning the EU model - such as the criterion of exclusive membership have never been adopted by West African organisations.

The rationale for West African organisations and their member states to emulate the EU model is related to the quest for international and local legitimacy (Gibb 2009).

Legitimacy is enhanced by mimicking, albeit only formally, a model that has elsewhere been successful. African intellectuals have complained that, as long as the integration process has tried to copy external models, it has remained disconnected from the local context (Adebajo 2012), paralleling the exogenous origin of African nation-state institutions. Unfortunately, the EU itself might have contributed to widening the gap. During the first phase of regional cooperation in Africa, the influence of the EU model is believed to have led African sub-regional organisations to set unrealistic economic goals and neglect key governance and security issues (Clapham 2001: 59). 


\section{Conclusion: prospects and recommendations}

Although still plagued by political tensions and security problems, West Africa is considerably less violent today than it was twenty years ago. It is difficult to establish a precise causal link between developments in regional integration and violence abatement, as global and national factors have also been at play. However, ECOWAS's diplomatic and military efforts, as well as its stigmatization of coups d'états and violations of democracy, have been arguably positively linked to the containment of violent conflicts.

At the same time, the link between economic integration and conflict transformation appears tenuous, also given the structural problems that economic integration faces in the region and the delays in ECOWAS's economic integration agenda. Among UEMOA countries, French security guarantees, rather than economic and monetary integration per se, seem to have given the greatest contribution to stability (but not necessarily to long term peace).

With regards to the EU, its contribution to conflict transformation through regional integration in West Africa is visible, but must not be overstated. Historically, the EU has favoured, both through its example and through concrete actions, an economy-driven model of integration. This has not proven to be fully fitting to conflict transformation goals in the region. Moreover, the EU's relations with West Africa have long been shaped by France's influence, which resulted in the EU prioritizing support for regional integration among the French-speaking countries over West Africa as a whole. 
Innovations in regional conflict prevention and management have been driven by ECOWAS and the EU has taken time in understanding its full potential. On a normative level, the EU has contributed to the evolution of ECOWAS's vision of security, encouraging the organisation to embrace democratic values and human rights, but the EU's role should not be exaggerated. Much of ECOWAS's normative evolution has been driven by normative changes at the global level and by the emergence of an epistemic community of practitioners of conflict prevention and resolution, with the EU being only one of the many actors. Today, the EU supports conflict transformation through regional integration with important financial means, but only a fraction of its aid effectively contributes to the reinforcement of regional governance.

\section{The Great Lakes and the EU: formal and informal regionalism and conflict transformation}

Sonja Theron ${ }^{15}$

\section{Introduction}

15 The author would like to thank Edgar Cizero Ntasano, who contributed towards an earlier version of this paper. 